\section{Tópicos poéticos que conducen a la infelicidad: de La Galatea al Persiles}

Recibido: 22/11/2019. Aceptado: 5/6/2020.

A la memoria de mi padre, mi modelo a seguir siempre.

\section{Sara Santa-Aguilar}

Universidad de La Rioja, España

sara-isabel.santa@unirioja.es
Palabras clave

lector mimético tópicos poéticos violación de expectativas poesía de Cervantes

Keywords

mimetic reader poetic topics violation of expectations Cervantes's poetry

From La Galatea to the Persiles, Cervantes's narrative is a rich metaliterary laboratory inhabited by different types of readers. The reader of poetry who expects his life to follow the rules of the poetic topics is one of them. It is a reader invariably doomed to failure due to the abyss that opens between his life and the poetic topics. The purpose of this article is to study this type of readers of poetry in the crossroads between the expectations of the literary genres that rule their stories and those of their poetic referents. The following characters will be analysed:Teolinda and Rosaura in La Galatea, Grisóstomo in Don Quixote, Ricardo in El amante liberal and the enamoured portuguese in the Persiles.

Si Stendhal titulaba el capítulo XIX de Rojo y Negro "Penser fait souffrir" (pensar hace sufrir), son varias las tramas de Cervantes que podríamos englobar bajo el título Lire fait souffrir (leer hace sufrir). Aunque no son pocas las apologías de la literatura que encontramos en las obras del alcalaíno, ${ }^{1}$ figuras capitales en su producción literaria -el mismo don Quijote, sin ir más lejos- dan detallada cuenta de la otra cara de la moneda, de los peligros que encierra la lectura.
1. Recuérdese el prólogo de las Novelas ejemplares, donde la colección es presentada como "una mesa de trucos, donde cada uno puede llegar a entretenerse sin daño de barras" (I: 52), o en el Quijote la opinión del ventero, que habla de las mil pesadumbres que le quita oír leer (I, 32), sin olvidar tampoco la defensa del mismo caballero manchego, quien recomienda al canónigo de Toledo que "lea estos libros [los de caballerías], y verá cómo le destierran la melancolía que tuviere, y le mejoran la condición, si acaso la tiene mala" (II, 50: 511). 
2. En el inicio del libro Ill de La República (386a-392c) se lleva a cabo una expurgación de pasajes de Homero, no bajo el criterio de la verdad (que se desarrolla en el libro X), sino de las consecuencias que puedan tener sobre el comportamiento del receptor, que en este caso es el guardián. Para los moralistas de los siglos XVI-XVII, los principales blancos de la preocupación resultan ser las mujeres, tanto si son doncellas, pues podrían aprender cosas nocivas para su inocencia en los libros, como si son casadas, pues podrían tomar ejemplo de mujeres infieles y aprender variadas artimañas para engañar a sus maridos. Respecto de las doncellas, resulta emblemática la advertencia de Francisco de Salazar, quien apunta a que la lectora de la obra de Rodríguez de Montalvo terminaría "desseando ser otra Oriana como allí, e verse servida de otro Amadís" y, lo que resultaría más preocupante, que "tras este desseo viene luego el procurarlo" (Obras II, fol. XIIIv-XIVr, citado por Ife, 1992: 30). Respecto de las casadas, advierte Juan Luis Vives: "por cierto es de reír la locura de los maridos que permiten a sus mujeres leer en tales libros, con los cuales aprenden a ser más maliciosamente perversas" (1943: 35). Para un detallado estudio de los argumentos platónicos y su relación con los debates de los moralistas de los siglos XVI-XVII remito a Ife (1992: 11-44).

3. Los libros de caballerías, con sus desenvueltas doncellas que invariablemente terminan en la cama de los valientes caballeros, suelen ser el principal objetivo de estos debates, pero, como advierte Ife (1992: 19), tras los ataques a este género suelen incluirse otras fórmulas que abarcan la ficción en general. Pasando a casos de obras particulares, no es de extrañarse que, por su contenido, obras como La Celestina tengan varios detractores entre los moralistas (Chevalier, 1976: 155-159), pero resultan más raras las condenas como la que hace Malón de Chaide en La conversión de la Magdalena (I: 23) a las obras de Boscán y Garcilaso.

4. Dice la dueña Dolorida, partidaria de expulsar a los poetas de "las buenas y concertadas repúblicas", que el abandono de sus obligaciones y la pérdida de la honestidad de Antonomasia se debió a unas coplas amorosas con

"unas agudezas que a modo de blandas espinas os atraviesan el alma y como rayos os hieren en ella" (II, 38: 843). Sin embargo, aclara que "no tienen ellos la culpa [los poetas], sino los simples que os alaban y las bobas que los creen; y si yo fuera la buena dueña que debía, no me habían de mover sus trasnochados conceptos, ni habría de creer ser verdad aquel decir 'vivo muriendo, ardo en el yelo, tiemblo en el fuego, espero sin esperanza, pártome y quédome', con otros imposibles de esta ralea, de que están sus escritos llenos" (II, 38: 844). En la seducción de Vicente de la Roca a Leandra, si bien no se desarrolla el tema con el detalle que tendrá en el episodio de la dueña Dolorida, también se resalta el papel de los versos: "enamoróla el oropel de sus vistosos trajes; encantáronla sus romances" (I, 51: 518).
Se trata de un tema que, antes que juego metaliterario en la genial "mesa de trucos" cervantina, corresponde a un debate fundamental en la reflexión de los moralistas contemporáneos a Cervantes. La literatura miente, ya lo advertía Platón en el libro X de La República. Pero ¿qué peligros se derivan de esto? Desde una perspectiva epistemológica o moral, el hecho de que se lleve a cabo un falseamiento de la realidad es problemático en sí mismo. El tema de las mentiras de la ficción se repite mecánicamente en los debates de los siglos XVI y XVII y el vocabulario de la época abunda en palabras que remiten a la falsedad, como "mentiras", "ficciones", "fábulas", "apócrifos", etc. (Ife, 1992: 32 y Castillo, 2016: 25). Pero no es esta la preocupación inmediata en la que más se detienen los moralistas, sino en la posibilidad -también de raigambre platónica- de que ciertas lecturas induzcan a pensamientos y comportamientos inapropiados. ${ }^{2}$ En definitiva, se trata de una preocupación por un tipo de lector particular, el lector mimético que se identifica con los personajes y pasa a desear e incluso a regir su comportamiento influido por lo que lee.

Cervantes entra activa y, podría decirse, obsesivamente, en esta reflexión, pero, naturalmente, no lo hará desde las estrechas coordenadas del debate moral. Los lectores ingenuos, en todos sus grados posibles, en manos del alcalaíno pasan a ser un rico reservorio para diversos desarrollos narrativos que le permitirán poner en escena un choque de trenes entre lo que acertadamente Martínez Bonati (1977) llamó diferentes "regiones de la imaginación", entendidas como diferentes principios de estilización: la correspondiente a las lecturas de los personajes y la de su propio mundo, donde pretenden trasplantar sus referentes librescos.

El tema de la lectura en la obra de Cervantes ha sido suficientemente abordado por la crítica, por lo cual limitaré mi análisis a un objeto mucho más puntual, que, a mi juicio, ha quedado a la sombra de lectores como don Quijote y no se le ha prestado atención: los lectores miméticos de poesía lírica.

A la luz de las advertencias de los moralistas sobre los peligros de la lectura, esta categoría podría resultar un poco extraña. Los debates suelen girar en torno a los peligros de la ficción que miente y da malos ejemplos. Pero ¿cómo miente la poesía lírica?, ¿qué mal ejemplo podría sacarse de Boscán o Garcilaso ${ }^{3}$ La creación de una voz poética es ya una construcción ficcional y, así mismo, puede serlo el sentimiento expresado, que, según la tradición literaria que se siga -amor cortés, pastoril, etc.-, se codificará de una u otra manera. Un lector ingenuo sería aquel que cree a pie juntillas que los sentimientos expresados son verdaderos e incluso podría llegar a estar incapacitado para distinguir como tales ciertos tópicos. Cervantes mismo, a través de personajes como Leandra, o la dueña Dolorida, advierte en el Quijote sobre la posibilidad de que esta poesía sirva como herramienta para seducir doncellas -y dueñas- desprevenidas, ${ }^{4}$ pero más allá del peligro para las destinatarias crédulas, el riesgo de la mímesis no parece entrar, en principio, en lo que se refiere a este género de poesía.

Si bien es cierto que en la poesía lírica no hay personajes en estricto sentido, cuyas vicisitudes den pie para que un lector decida imitarlas, la expresión de sentimientos resulta más que propicia para el proceso de identificación. Cervantes capta esta posibilidad y crea un tipo de personaje que muestra como un conocedor de la lírica de su tiempo y que pretende trasladar, ya no episodios, sino tópicos poéticos a su vida. En una actitud que hoy podríamos llamar bovarista, pretende que su historia se rija por estos tópicos y termina labrando con ello los caminos de su infelicidad.

La particular propuesta (anti)pastoril que lleva a cabo Cervantes en La Galatea es sin duda alguna un campo fértil para el florecimiento de tales personajes. En su primera novela, el alcalaíno explora las expectativas que le ofrece este género literario 
para terminar negándolas sistemáticamente en un rico entrecruzamiento con otros géneros. Varios personajes fundan sus esperanzas en las promesas de felicidad que les ofrece una determinada tradición literaria que parece regir sus vidas, pero en los impredecibles universos cervantinos descubrirán con desconcierto su error.

Dentro de todos los personajes cuyo destino sigue esta línea general, Teolinda y Rosaura, protagonistas de dos historias que no en vano convergen, son las que específicamente fundan sus esperanzas y su actuar en tópicos poéticos. A partir de dichos tópicos, ambos personajes solo desviarán el desarrollo feliz al que naturalmente tienden sus historias y las conducirán al más estrepitoso fracaso.

Teolinda, perfecta pastora literaria, inicialmente desamorada, conoce en una celebración a otro bello y discreto pastor de esta misma condición, Artidoro, y de tal encuentro surge, en medio de danzas y cantos, un amor correspondido. No hay celos, no hay rivales, no hay diferencias sociales ni voluntades paternas contrarias, y todo parece apuntar a un feliz desenlace sin obstáculos. Dice la pastora:

le di respuesta tal como yo deseaba dársela, quedando, en resolución, concertado en que él se fuese a su aldea, y que, de allí a pocos días, con alguna honrosa tercería me enviase a pedir por esposa a mis padres [...] el valor y calidad de Artidoro era tal que mi padre sería contento de recebirle por yerno (241).

Sin embargo, impone al desarrollo de sus amores un modelo literario completamente extraño a su contexto pastoril, además de innecesario en su situación: el del amor cortés. El primer poema que canta la pastora manifestando su amor ante Artidoro resulta ser un villancico, en el que establece la metáfora de la puerta y la llave para referirse al secreto y al recato como elementos que garantizarían la felicidad de los amantes. Este modelo, como apunta Trabado Cabado, presenta un choque con lo pastoril (2000: 223) y, según López Estrada (1999: 239, nota 9), iría en contravía incluso de la forma popular del villancico en la que la pastora decide desarrollarlo:

En los estados de amor nadie llega a ser perfeto sino el honesto y secreto.

Para llegar al süave gusto de amor, si se acierta, es el secreto la puerta y la honestidad, la llave; y esta entrada no la sabe quien presume de discreto sino el honesto y secreto.

Es ya caso averiguado, que no se puede negar, que a veces pierde el hablar lo que el callar ha ganado; $y$, el que fuere enamorado jamás se verá en aprieto, si fuere honesto y secreto

Cuando una parlera lengua y unos atrevidos ojos 
5. En otro estudio (Santa-Aguilar, 2018), analizo la historia de Teolinda a la luz de su estructura de comedia de enredos que promete un final feliz. Sin embargo, estas promesas se ven sistemáticamente violadas, razón por la cual me refiero a esta historia como una tragedia de enredos.

6. En la historia de Teolinda, si bien al final queda al descubierto el engaño de su hermana, esto no trae ninguna solución y el pastor continúa casado con Leonarda. Dice Teolinda: "y puesto que ya él lo sabe, aunque debe de haber sentido la burla, hala disimulado como discreto" (618-619). El conocimiento de los engaños de Leonarda no trae ninguna justicia: Teolinda queda condenada a la desdicha y termina huyendo de su aldea y de su casa "por no verla gozar de la [dicha] que por derecho se me debía" (619).

7. Como caso emblemático recuérdese la historia de Belisa en la Diana de Montemayor: Belisa ve que el padre de su amado (enamorado también de ella) lo mata y después se suicida. Sin embargo, después se revela que esos actos no fueron llevados a cabo, sino que un nigromante hizo que Belisa viera tales apariciones. También la historia de Montano en la Diana de Gil Polo: el personaje, movido por los engaños de Felisarda, queda a punto de matar a su padre, creyendo dar muerte al hombre que cometía adulterio con su madrastra. La tensión se mantiene, pero, como es de esperar, Montano reconoce su error y no lleva a cabo el asesinato. Para

el tema de la violencia que no llega

a feliz resolución en la propuesta cervantina ver Mujica (1986).

\author{
suelen causar mil enojos \\ y poner el alma en mengua, \\ tanto este dolor se desmengua \\ y se libra de este aprieto \\ el que es honesto y secreto (239-240).
}

Los enamorados trasladan el tópico, de por sí extraño en la poesía pastoril, a la trama, al desarrollo de sus historias; deciden seguir esta receta poética para "llegar al süave gusto de amor" sin "verse jamás en aprieto". Sin embargo, aplicar tal fórmula en contextos donde no es pertinente, no puede traer sino problemas, los "aprietos" de los que se veía libre esta historia. Por mantener el secreto, Leonarda, gemela de Teolinda, pone en duda la honestidad de su hermana cuando escucha los requiebros que Artidoro le dedica tomándola por Teolinda y le responde duramente, ante lo cual Artidoro huye desconsolado convencido de la inconstancia de su pastora amada. Como bien recordará el lector, este es solo el punto de partida para el desarrollo de la más descarnada tragedia de enredos, ${ }^{5}$ en la que Leonarda termina enamorándose del gemelo de Artidoro, pero, al no ser correspondida por este, busca al amado de su hermana, y, haciéndose pasar por Teolinda, se casa con él, dejando a nuestra pastora sumida en una desdicha irreparable. ${ }^{6}$

La tradición del amor cortés trasvasada en la pastoril detona la desdicha. Sin embargo, cabe resaltar que es solo el detonante, pues en la peculiar arcadia cervantina la tradición pastoril tampoco cumple sus promesas de felicidad. Si bien la novela pastoril no puede considerarse como un género de felicidad y armonía estática, pues los celos, los amores no correspondidos, los malentendidos y hasta los engaños son el motor de las tramas, la resolución de todos los conflictos es invariablemente el punto de llegada. ${ }^{7}$ Por el contrario, estos enredos cervantinos no llegan a feliz resolución porque, además del engaño y las malas intenciones, cabe la posibilidad de que estos triunfen sobre los honestos amores correspondidos de los pastores.

Hermana de Teolinda en desatinos poéticos e infortunios en La Galatea es la cortesana Rosaura, una dama que se disfraza de pastora para ir tras su amado caballero Grisaldo, después de enterarse de que este se ha comprometido con Leopersia. En el desarrollo de la trama se revela que Rosaura, para causar los celos de Grisaldo, había fingido amar a otro galán, Artandro, y había terminado prometiéndose a este en matrimonio, ante lo cual Grisaldo, resignado y presionado por su padre, se compromete con Leopersia.

También en este caso el detonante de los problemas, a saber, aquello que impide el feliz matrimonio de Rosaura con Grisaldo al que tiende naturalmente la historia, son los tópicos poéticos. Rosaura pretende que su vida se rija por tópicos como el amor incondicional frente al desdén o la fuerza de los lazos de la hermosura. Así, trasvasa tales motivos a un contexto en el que no solo no son necesarios, sino que, como en la historia de Teolinda, resultan inconvenientes, pues su mundo obedece a otro principio de estilización, el de la novela cortesana, en el que son constitutivos elementos como la presión paterna que lleva a Grisaldo a comprometerse con Leopersia ante los reiterados e inexplicables desdenes de su amada. Refiere Rosaura:

tomé la ocasión de pedirle celos, aunque fingidos, solo por hacer prueba de la entereza de su fe [...] confiada en que los lazos que mi hermosura había echado al alma de Grisaldo no podían tan fácilmente ser rompidos ni aun tocados de cualquier belleza; mas salióme tan al revés mi confianza como me lo mostró Grisaldo, el cual, cansado de mis necios y esquivos desdenes, tuvo por bien dejarme y venir obediente al mandato de su padre (394-395). 
Como en una novela pastoril arquetípica, el espacio arcádico es donde Rosaura encuentra a su amado y el dolor de ambos promete alcanzar término, pues los enamorados reconocen su amor mutuo y planean casarse. Sin embargo, ya se había sugerido que la realidad de Rosaura no se regía por las promesas de la literatura y, en efecto, llega el burlado Artandro y la rapta, en un episodio que plantea un abierto contraste con el rapto de las ninfas en la Diana de Gil Polo, pues para Rosaura no habrá Felismenas que con sus destrezas guerreras venzan a todos los raptores, sino un Elicio y un Damón que resultan vencidos al ser superados en número por los criados de Artandro. ${ }^{8}$ El mundo pastoril, en esta historia, no es el arquetípico locus amoenus, en el que los adoloridos cortesanos que se disfrazan de pastores encuentran fin a sus desdichas, pues, como se vio, esta arcadia no garantiza la felicidad ni la armonía y, paradójicamente, es por intentar buscarla imitando tópicos poéticos que Rosaura y Teolinda caen en la desdicha, en un universo que no les va a garantizar la posibilidad de salir de ella.

También en diálogo con la literatura pastoril, pero ahora entre los sinuosos andurriales del Quijote poblados ante todo por cabreros, aparece la siguiente víctima de la poesía: Grisóstomo. Este personaje y su "Canción desesperada" han contado con bastante atención por parte de la crítica, tanto por el llamativo tema del suicidio como por el valor estético de la canción.?

Grisóstomo, como estudiante que se viste de pastor, resulta atractivo para el estudio de los personajes enfermos de literatura. Sin embargo, no analizaré su proyecto de hacerse pastor desde esta perspectiva, pues más que un proyecto vital inspirado en la literatura, como sería el caso de don Quijote o de Rutilio en el Persiles, es una decisión ante todo práctica: ${ }^{10}$ Grisóstomo no se hace pastor movido por el beatusille, sino porque la bella Marcela ha decidido vestirse de pastora, y con ese hábito tanto él como los otros enamorados pueden seguirla, trayendo como daño colateral esta pastoril y no fingida arcadia de bellos y discretos mancebos enamorados que cantan sus desdichas en el Quijote.

Otros son los motivos por los que, a mi juicio, Grisóstomo también se puede hermanar con Teolinda y Rosaura en el infeliz (y en este caso podríamos decir desesperado) intento de experimentar tópicos literarios que no tienen que ver con su situación. A diferencia de los casos de las dos pastoras de La Galatea, el de Grisóstomo nunca promete un buen final, pues es la historia de un amor no correspondido que ha puesto su mira en una bella desamorada que no atiende a sus ruegos ni a los de nadie. A la luz de este contexto, llaman la atención la cuarta y la quinta estrofa de la "Canción desesperada", donde el estudiante-pastor declara que padece celos, temor de olvido y ausencia:

Mata un desdén, atierra la paciencia, o verdadera o falsa, una sospecha; matan los celos con rigor más fuerte; desconcierta la vida larga ausencia; contra un temor de olvido no aprovecha firme esperanza de dichosa suerte... En todo hay cierta, inevitable muerte; mas yo, imilagro nunca visto!, vivo celoso, ausente, desdeñado y cierto de las sospechas que me tienen muerto, y en el olvido en quien mi fuego avivo, $y$, entre tantos tormentos, nunca alcanza mi vista a ver en sombra a la esperanza, ni yo, desesperado, la procuro,
8. Avalle-Arce establece este paralelo con el rapto de las ninfas en La Diana de Gil Polo y resalta como diferencia fundamental que, aparte de que los personajes son ninfas y sátiros en la obra de Gil Polo, el rapto ni siquiera se lleva a cabo, pues aparece Felismena y con sus dotes guerreras vence a los captores (1975: 236-237).

9. Resaltan por su rigor desde una aproximación literaria los estudios de Lapesa (1988), Gaylord (2001), Alonso (2008) y Romo Feito (2012: 143). En lo que se refiere al suicidio, Zimic recoge el debate crítico que este tema ha suscitado y salda la cuestión al traer las evidencias textuales, tanto en la narración como en la Canción, que apuntan al explícito suicidio del personaje y destacando que "nunca se contempla, ni en 'lo que dice la prosa' ni en 'lo que dicen los versos' como una realidad baciyélmica" (2003: 55). En lo que concierne a la Canción, Lapesa (1988: 101) destaca el tema del suicidio tanto en la versión impresa como en el manuscrito.

10. Esta posibilidad de acoger la vida pastoril o la vida retirada como una salida ante todo práctica también se encuentra en el Persiles. Si bien el italiano Rutilio la acoge movido por el tópico del Beatus, sus predecesores, Renato y Eusebia, llegan a ella como consecuencia de una trama de engaños en la que su honra se ha visto comprometida. Así, una vez se aclaran los enredos de esta historia y la honra es restituida, los personajes abandonan sus rústicos hábitos y vuelven a sus lugares de proveniencia. 
11. Para este debate remito a Zimic (2003). Se trata del manuscrito de la Biblioteca Colombina de Sevilla. Vicente Gaos en su edición crítica de la poesía (1981) anota las variantes frente al manuscrito colombino.

12. Concuerdo con Álvarez (2019: 143) en su interpretación de la incongruencia como parte de la caracterización de Grisóstomo.

Sin embargo, más que la locura dis-

torsionadora que resalta Álvarez, me interesa enfatizar la locura

literaria, el querer vivir artificialmente unos tópicos poéticos.

13. Para estos elementos como tópicos en la literatura pastoril, recuérdese que justamente desdenes, celos y ausencia, junto con la muerte, son los dolores que aquejan en La Galatea a los cuatro discretos y lastimados pastores, quienes incluso llegan a ponerlos en escena en la égloga que representan en las bodas de Daranio y Silveria. Para un análisis de esta puesta en escena ver Santa-Aguilar (2017). Otro tratamiento poético de los mismos, ya en el Quijote, es el ovillejo de Cardenio, solo que, a diferencia de Grisóstomo, en la historia de Cardenio sí hay razones para que el personaje los padezca. antes, por extremarme en mi querella, estar sin ella eternamente juro.

¿Puédese, por ventura, en un instante esperar y temer, o es bien hacello siendo las causas del temor más ciertas? ¿Tengo, si el duro celo está delante, de cerrar estos ojos, si he de vello por mil heridas en el alma abiertas? ¿Quién no abrirá de par en par las puertas a la desconfianza, cuando mira descubierto el desdén, y las sospechas, ¡oh amarga conversión!, verdades hechas, y la limpia verdad vuelta en mentira? ¡Oh en el reino de amor fieros tiranos celos!, ponedme un hierro en estas manos. Dame, desdén, una torcida soga. Mas, iay de mí!, que con crüel victoria vuestra memoria el sufrimiento ahoga (I, 14: 121).

La no correspondencia de estos motivos con la historia de Grisóstomo es evidente hasta para los personajes que asisten al entierro, como Vivaldo, quien: "dijo que no le parecía que conformaba con la relación que él había oído del recato y bondad de Marcela, porque en ella se quejaba Grisóstomo de celos, sospechas y de ausencia, todo en perjuicio del buen crédito y buena fama de Marcela" (I, 14: 124). Pero más interesante que la incongruencia es la explicación que tiene que dar su leal amigo Ambrosio:

...para que, señor, os satisfagáis desa duda, es bien que sepáis que cuando este desdichado escribió esta canción estaba ausente de Marcela, de quien él se había ausentado por su voluntad, por ver si usaba con él la ausencia de sus ordinarios fueros; y como al enamorado ausente no hay cosa que no le fatigue ni temor que no le alcance, así le fatigaban a Grisóstomo los celos imaginados y las sospechas temidas como si fueran verdaderas (I, 14: 124).

También la crítica se ha ocupado de esta anomalía, que ha sido interpretada como un descuido cometido por Cervantes al insertar en su novela poemas escritos con anterioridad. Sin embargo, como destaca Zimic (2003: 54), aunque el poema fue compuesto previamente, Cervantes lo modificó para su inserción en este episodio y no llevó a cabo ningún cambio sobre los tópicos de los celos, el olvido o la ausencia. ${ }^{11}$ De este modo, no resulta acertado considerar la réplica de Vivaldo y la explicación de Ambrosio como una enmienda hecha a posteriori (la cercanía del poema y de la réplica también nos hacen pensar en lo injustificado que resulta argüir en este punto un olvido cervantino), sino un consciente giro que le da Cervantes al episodio y a la caracterización del personaje retomando una línea que ya había desarrollado con Rosaura y Teolinda en La Galatea. ${ }^{12}$ Así, propone un Grisóstomo que, como sus antecesoras pastoriles, decide vivir artificialmente en carne propia unos tópicos poéticos que no vienen a cuento con su historia: determina esta ausencia voluntaria y termina padeciendo imaginadamente los celos y el olvido de su pastora, que lo llevan a un desastroso final. ${ }^{13}$

Sin embargo, cabe resaltar en este caso que, aunque Grisóstomo es un personaje que intenta vivir artificialmente unos referentes poéticos, sí logra cierta concordancia entre sus ideales literarios y su realidad, sí está construido, hasta cierto punto, bajo los mismos principios de estilización: tiene todas las características de un arquetípico pastor literario y conoce, realmente, a una hermosa y desamorada mujer. Su 
historia, aunque rica y compleja en matices, sí tiene un barniz idealizante que no está garantizado en el mundo de don Quijote. En otras palabras, Grisóstomo no tiene que proyectar sus ideales sobre una realidad diametralmente opuesta a ellos, como le sucede a don Quijote con sus carnes enjutas y su rolliza Dulcinea que, no obstante, describe a Vivaldo justo antes del entierro de Grisóstomo como la realización de un ideal literario, como si fuera una Marcela, una mujer en quien

\begin{abstract}
se vienen a hacer verdaderos todos los imposibles y quiméricos atributos de belleza que los poetas dan a sus damas: que sus cabellos son oro, su frente campos elíseos, sus cejas arcos del cielo, sus ojos soles, sus mejillas rosas, sus labios corales, perlas sus dientes, alabastro su cuello, mármol su pecho, marfil sus manos, su blancura nieve (I, 13: 115, énfasis mío).
\end{abstract}

Siguiendo por el lado trágico, por los personajes a quienes el amor conduce a la muerte, llegamos al enamorado portugués del Persiles, quien, antes de morir de pena, canta en medio de las heladas aguas septentrionales:
Mar sesgo, viento largo, estrella clara, camino aunque no usado alegre y cierto, al hermoso, al seguro, al capaz puerto llevan la nave vuestra única y rara.

\section{En Scilas ni en Caribdis no repara siguiendo su derrota al descubierto, \\ Con todo, si os faltara la esperanza de llegar a este puerto, no por eso giréis las velas, que será simpleza.} ni en peligro que el mar tenga encubierto, que limpia honestidad su curso para.
Que es enemigo amor de la mudanza y nunca tuvo próspero suceso el que no se quilata en la firmeza (196).

Este soneto ha sido largamente analizado por la crítica, tanto por su valor literario como poesía seria cervantina como por la función que cumple en la novela. ${ }^{14}$ Una de las aproximaciones que más ha sido desarrollada por los estudiosos es la de Joaquín Casalduero, para quien estos versos "cristalizan" el sentido de la novela (1947: 56-60), pues muestran cómo la honestidad y la firmeza conducen a un buen fin (que es lo que ocurrirá con las peripecias de Periandro y Auristela).

No obstante, si se lee desde su contexto inmediato de enunciación, ofrece interesantes matices frente a la máxima casaldueriana. Cabe resaltar entonces que, antes que remitir a la historia de Periandro y Auristela, el soneto se refiere a otra historia: la historia de su autor ficcional, el portugués Manuel de Sosa Coitiño y su prometida Leonora, quien, en el momento en que iban a casarse, lo deja para hacerse religiosa. Desde este contexto, el soneto contiene la historia de Leonora, quien, como se lee en el primer cuarteto, ha elegido un camino "no usado" que promete "feliz puerto". Cabe resaltar en este punto, con estudiosos como Isabel Lozano-Renieblas (2004: 305), Mercedes Alcalá-Galán (2009: 191) o José Montero Reguera (2011: 254-255 y 2013: 129-131), que hay una disociación entre el contenido del poema y su autor, pues el abandonado amante no está cantando su amor, sino el de Leonora por Cristo. El soneto promete un buen fin como resultado de la firmeza de Leonora, pero el fin de Manuel, firme también en su amor, será morir de tristeza al terminar su canto.
14. Para una historia de la buena acogida de este soneto en la crítica ver Lozano-Renieblas (2004: 300301). Pedro Ruiz Pérez alude a "un lirismo inhabitual en las poesías sueltas de Cervantes" (1985: 171) y estudia su filiación con una estética manierista, propuesta que acoge Mata Induráin (2004: 661). También Pelorson destaca sus cualidades (2003: 68-69). Para un análisis de la estructura del soneto remito a Mata Induráin (2004). Para un detenido análisis de las imágenes y su relación/ contraste con la lírica petrarquista ver Lozano-Renieblas (2004). 
15. También Zimic señala que, a través de este soneto, se da un irónico contraste (2005: 45) entre la poesía y algunos casos particulares de la realidad, pues su autor ficcional es justamente el personaje en quien no se cumplen las promesas de su propia literatura.

16. Casalduero (1947: 78) y Hutton (1981) juzgan al portugués como soberbio, y a la luz de esta consideración interpretan su fracaso.

Sin embargo, no hay indicios de tal soberbia en el texto, como sí los hay de su honestidad y firmeza. Para el enamorado portugués como el amante firme del soneto ver Lozano-Renieblas (2004: 306)

y Mata Induráin (2004: 660).
Este trágico desenlace y el contraste con el soneto, como apunta Zimic, suele ser pasado por alto en una lectura que solo se centre en la exaltación de las bodas místicas (2005: 38). ¿Acaso no auguraba el soneto un buen fin a los amantes firmes? En palabras de Michael Armstrong-Roche, la historia del enamorado portugués "se ocupa de anular las promesas anunciadas por el soneto" (2011: 27), ${ }^{15}$ pues Manuel de Sosa Coitiño se construye como el enamorado firme y honesto de su poema, ${ }^{16}$ que, ante la petición del padre de la dama de esperar unos años hasta que alcance edad de casarse, decide llevar "el escudo de la esperanza" sirviéndola "a sombra de su honesta pretensión" (200), un enamorado que va a la guerra en Berbería por dos años y regresa sin mudanza en su sentir, pero con quien no se cumple la justicia poética que anuncian sus propios versos para los amantes que encarnan sus condiciones. Manuel entra al Persiles como la voz poética que enuncia esta justicia para el amante firme, pero muere como consecuencia del fracaso de su máxima. Su muerte es el resultado del abismo entre sus esperanzas, que trasluce en el poema, y su vida. Desde esta perspectiva, si bien no es exactamente como los personajes anteriormente analizados, un bovarista que labre su propia desdicha trasladando tópicos poéticos en situaciones donde no son pertinentes, comparte con ellos la experiencia de una dolorosa no correspondencia entre las promesas de la poesía y su realidad.

Los tópicos poéticos no rigen los universos novelísticos del alcalaíno, y los enfermos de poesía parecen estar destinados al fracaso. Sin embargo, este fracaso puede tener dos caras, y aunque la más natural y por ello la más recurrente es la cara trágica, hay una veta cómica que Cervantes desarrolla en El amante liberal.

En esta novela, Ricardo, el protagonista, es otro personaje sobresaturado de literatura, quien, si bien no pretende vivir sus referentes poéticos, sí los trae a colación en las situaciones más inadecuadas. Un indicio de esto lo da el comienzo de la novela, en el que el caballero cautivo interpela a las ruinas de Nicosia, invadida por los turcos:

—iOh lamentables ruinas de la desdichada Nicosia, apenas enjutas de la sangre de vuestros valerosos y mal afortunados defensores! Si como carecéis de sentido le tuviérades ahora, en esta soledad donde estamos, pudiéramos lamentar juntas nuestras desgracias, y quizá el haber hallado compañía en ellas aliviara nuestro tormento. Esta esperanza os puede haber quedado, imal derribados torreones!, que otra vez, aunque no para tan justa defensa como la en que os derribaron, os podéis ver levantados (I: 137).

Este lamento del personaje apenas es pronunciado es ridiculizado por el narrador, quien interpreta el recurso poético del apóstrofe no como un artificio literario, sino como una muestra del trastornado juicio de Ricardo, que habla a las murallas "como si ellas fueran capaces de entenderle" (I: 137), patología que explica como "propia condición de los afligidos que, llevados de sus imaginaciones, hacen y dicen cosas ajenas de toda razón y buen discurso" (I: 137).

Pero el personaje no solo convierte su desdicha de cautivo en el apóstrofe a los muros de Nicosia, también refiere que justo antes de ser preso, estaba desafiando a su rival en materia amorosa, Cornelio, pero antes de desenvainar su espada lo insulta en otra extensa intervención retórica llena de referentes poéticos. Lo llama "nuevo Ganimedes", aludiendo a la homosexualidad del copero de Zeus, y le achaca que "si esa tu reposada condición tuviera Aquiles, bien seguro estuviera Ulises de no salir con su empresa" (I: 144), reiterando esta acusación de amaneramiento a través de la mención al episodio de la Ilíada en que Tetis disfraza a Aquiles de mujer para que no vaya a la guerra de Troya, pero el guerrero disfrazado no puede contenerse y toma las espléndidas armas que le muestra Ulises (cosa que Cornelio no haría), hecho que lo lleva a ser descubierto. La escena resulta de gran comicidad, pues la palabrería del 
personaje impide el rápido actuar que requiere esta trama de peripecias y da tiempo no solo para que lleguen los defensores de Cornelio, sino también los turcos que terminan raptándolo junto con su amada Leonisa.

Si la inadecuación de un tópico poético era lo que detonaba la trama de enredos en la historia de Teolinda, podría decirse que en El amante liberal es lo que detona la trama morisco-bizantina de cautiverio. Sin embargo, a diferencia de lo que ocurre con Teolinda, en este caso no se trata de un desatinado intento de regir la propia vida por tópicos poéticos. A través de Ricardo, Cervantes desarrolla otra cara de la inadecuación y otro peligro de la lectura de poesía, el peligro para el buen lector, que ya advertía Saavedra Fajardo en sus Empresas: "enamorado de sus conceptos el entendimiento, como de su canto el ruiseñor, no sabe dejar de pensar en ellos, y se afila tanto con la sutileza de la poesía, que después se embota y tuerce en lo duro y áspero del gobierno" (Empresa 6: 52). Ricardo no pretende vivir los tópicos, pero tampoco "sabe dejar de pensar en ellos" y los trae a colación sean o no pertinentes, cosa que, si bien no conduce a la muerte $o$ a desdichas irreparables, también puede resultar más que inconveniente.

Cervantes propone una reflexión metaliteraria transversal de La Galatea al Persiles sobre los lectores de poesía. La poesía puede generar los mismos efectos que las novelas. Seduce, obsesiona y también se presta para que un mal lector decida imitarla. Naturalmente, desde la perspectiva de Cervantes el foco de esta reflexión no será el mal ejemplo o los posibles deseos que las expresiones de sentimientos de las voces líricas puedan encender en los receptores. Más aún, el alcalaíno escoge varios casos que podrían ser considerados buenos ejemplos, como un amor honesto y secreto en el caso de Teolinda, o la firmeza del enamorado en el caso de Manuel.

Un mal lector de poesía, al igual que un mal lector de ficción, es quien cree que es verdad lo que lee. La caricatura extrema la presenta el licenciado Vidriera, cuando, al hablar de la pobreza de los poetas, advierte que podrían ser ricos, si quisieran, pues tienen damas de cabellos de oro, ojos de esmeraldas, etc. Sin embargo, más allá de esta cómica lectura literal de los tópicos (con el riesgo que conlleva para las bellezas áureas), el peligro para el mal lector de poesía es creer que sus referentes literarios son operativos en su mundo. Los caminos de la desdicha se labran principalmente porque los personajes pretenden trasladar a su realidad la lógica de las tradiciones poéticas que leen, o, en otras palabras, esperan que su mundo se rija por los mismos principios de estilización. En definitiva, se trata -muy cervantinamente- de un asunto de expectativas frustradas, del fracaso de las fórmulas fijas en unos horizontes narrativos mucho más amplios, donde convergen, se sobreponen y chocan entre sí todas las regiones de la imaginación. 


\section{Q Bibliografía}

»Alcalá-Galán, M. (2009). Escritura desatada: poéticas de la representación en Cervantes. Alcalá de Henares: Centro de Estudios Cervantinos.

»Alonso, A. (2008). “La 'canción desesperada' de Cervantes: cancioneros, modelos italianos y sensibilidad romántica". En: Matas Caballero, J. y Balcells Doménech, J. M. (ed.), Cervantes y su tiempo. León: Universidad de León, 109-121.

»Álvarez, E. (2019). La poesía, señor hidalgo... Funciones de la poesía en el Quijote. Ciudad de México: Grañén Porrúa.

»Armstrong-Roche, M. (2011). "Un replanteamiento paradoxográfico de la ortodoxia religiosa, política y social en Cervantes: el mito gótico y el episodio de Sosa y Leonor en el Persiles". En: Rivero Iglesias, C. (ed.), Ortodoxia y heterodoxia en Cervantes. Alcalá de Henares: Asociación de Cervantistas/Centro de Estudios Cervantinos, 15-32.

"Avalle-Arce, J. B. (1975). “Cervantes”. En: La novela pastoril española. Madrid: Istmo, 229-263.

"Casalduero, J. (1947). Sentido y forma de Los trabajos de Persiles y Sigismunda. Buenos Aires: Sudamericana.

» Castillo Gómez, A. (2016). “'Del donoso y grande escrutinio’: La lectura entre la norma y la trasgresión”. En: Leer y oír leer. Ensayos sobre la lectura en los Siglos de Oro. Madrid: Iberoamericana, 19-38.

»Cervantes Saavedra, M. de (1999). La Galatea. F. Edición de López Estrada y M. T. López García-Berdoy. Madrid: Cátedra.

»Cervantes Saavedra, M. de (2004). Don Quijote de la Mancha. Edición de F. Rico. San Pablo: Real Academia Española/Asociación de Academias de la Lengua Española/Alfaguara.

»Cervantes Saavedra, M. de (2007). Novelas ejemplares. Edición de H. Sieber. Madrid: Cátedra.

»Cervantes Saavedra, M. de (2004). Los trabajos de Persiles y Sigismunda. Edición de C. Romero Muñoz. Madrid: Cátedra.

»Cervantes Saavedra, M. de (1981). Poesía completa. Edición de V. Gaos. Madrid: Castalia.

»Chevalier, M. (1976). Lecturay lectores en la España del siglo XVIy XVII. Madrid: Turner.

" Gaylord, M. (2001). “Voces y razones en la Canción desesperada de Grisóstomo”. En: Lozano-Renieblas, I. y Mercado, J. C. (ed.), Silva: studia philologica in honorem Isaías Lerner. Madrid: Castalia, 287-300.

» Gil Polo, G. (1988). Diana enamorada. Edición de F. López Estrada. Madrid: Castalia.

»Hutton, L. J. (1981). “El enamorado portugués del Persiles de Cervantes". En: Criado de Val, M. (ed.), Cervantes: su obra y su mundo. Madrid: EDI-6, 465-469.

»Ife, B. W. (1992). “La ficción a juicio”. En: Lectura y ficción en el Siglo de Oro. Las razones de la picaresca. Barcelona: Crítica, 11-44. 
»Lapesa, R. (1988). “La descendencia hispano-portuguesa de una canción petrarquesca de Garcilaso a Camões y Cervantes”. En: De Ayala a Ayala. Madrid: Bella Bellatrix, 83-104.

"Lozano-Renieblas, I. (1998). Cervantes y el mundo del "Persiles". Alcalá de Henares: Centro de Estudios Cervantinos.

»Lozano-Renieblas, I. (2004). “'Mar sesgo, viento largo, estrella clara’ o la metáfora de la nave de amor en el Persiles”. Anales Cervantinos, 36, 299-308.

» Malón de Chaide, P. (1959). La conversión de la Magdalena. Edición de F. García. Madrid: Espasa-Calpe.

" Martínez Bonati, F. (1977). “Cervantes y las regiones de la imaginación”. Dispositio, 2.4, 28-53.

» Mata Induráin, C. (2004). “Algo más sobre Cervantes poeta: a propósito de los sonetos del Persiles”. En: Villar Lecumberri, A. (ed.), Peregrinamente peregrinos. Actas del V Congreso Internacional de la Asociación de Cervantistas. Lisboa: Asociación de Cervantistas, 651-676.

» Montemayor, J. de (1991). La Diana. Edición de A. Rallo. Madrid: Cátedra.

»Montero Reguera, J. (2011). “Heterodoxias poéticas cervantinas. (Prolegómenos para una edición crítica de la poesía de Cervantes)". En: Rivero Iglesias, C. (ed.), Ortodoxia y heterodoxia en Cervantes. Alcalá de Henares: Asociación de Cervantistas/Centro de Estudios Cervantinos, 245-271.

» Montero Reguera, J. (2013). “La poesía. Hacia una nueva edición”. En: Fernández Rodríguez, D. (ed.), Los textos de Cervantes. Madrid: Centro para la Edición de los Clásicos Españoles, 119-163.

" Mujica, B. (1986). “Cervantes's Blood-Spattered Arcadia: La Galatea”. Iberian Pastoral Characters. Scripta Humanistica, 30, 171-209.

»Pelorson, J. M. (2003). El desafío del «Persiles». Toulouse: Presses Universitaires du Mirail.

»Platón (1988). La República. Madrid: Gredos. (Traducción de C. Eggers Lan)

»Romo Feito, F. (2012). "Cervantes ante la palabra lírica: el Quijote". Anales Cervantinos, 44, 133-158.

» Ruiz Pérez, P. (1985). “El manierismo en la poesía de Cervantes”. Edad de Oro, 4, 165-177.

"Saavedra Fajardo, D. (1988). Empresas políticas. Edición de F. J. Díez de Revenga. Barcelona: Planeta.

»Santa-Aguilar, S. (2017). “'En el humilde teatro': paradojas de la puesta en escena de los cuatro discretos y lastimados pastores en La Galatea". Anuario de Estudios Cervantinos, 13, 265-278.

"Santa-Aguilar, S. (2018). “La Galatea y las expectativas de una tradición literaria: el caso de Teolinda”. Hipogrifo. Revista de literatura y cultura del Siglo de Oro, 6, 2, 283-295.

»Trabado Cabado, J. M. (200o). Poética y pragmática del discurso lírico. El cancionero pastoril de La Galatea. Madrid: Consejo Superior de Investigaciones Científicas.

»Vives, J. L. (1943). Instrucción de la mujer cristiana. Buenos Aires: Austral.

"Zimic, S. (2003). Los cuentos y las novelas del Quijote. Madrid/Barcelona: Iberoamericana/Vervuert.

»Zimic, S. (2005). Cuentos y episodios del Persiles: de la isla bárbara a una apoteosis del amor humano. Pontevedra: Mirabel. 
